\title{
Evaluation of the Quality of Bovine Milk of the Livestock Farms of Suscal, Cañar, Ecuador
}

Keywords: Quality; bovine milk; physicochemical; microbiological; organoleptic

\begin{abstract}
Cow's milk is an integral product that provides essential nutrients for health, and it is consumed worldwide. In Ecuador, the INEN 9:2015 (Ecuadorian Institute for Standardization), standards establish quality standards for production, distribution and marketing. They are supervised by Agrocalidad and ARCSA, which guarantees that the milk is fit for consumption. However, these practices are unknown to small producers. Therefore, in the present study, the milk quality (physicochemical properties, microbiological analysis and organoleptic tests) was determined in different rural areas of Suscal livestock farms, province of Cañar. The data was analyzed using a multifactorial ANOVA using SAS. The separation of means, the Tukey test was used at a significance level $(P<0,05)$. And the Pearson correlation test was performed. The results were, in physicochemical properties: the average acidity of $14.25^{\circ} \mathrm{D}$; protein of $3.13 \%$; and fat of $4.03 \%$. In the microbiological analysis: the mesophilic aerobes in solution -4 were 74.37 CFU and 162.03 CFU at 24 and 48 hours respectively; and somatic cells of $243333.33 \mathrm{v} / \mathrm{cm}^{3}$. In organoleptic characteristics: the color was opalescent white and slightly yellowish; the smell was milky smooth and free of strange odors; and the texture of the milk was homogeneous and free of foreign matter. Finally, total solids are highly correlated with protein and fat, which is positive.
\end{abstract}

\section{Introduction}

Milk is the indispensable food of newborn mammals, considered one of the most complete foods, and the composition of nutrients is balanced [1]. As for cow's milk, it is an integral food, which is consumed worldwide, which is very beneficial for humans, especially for children; due to the amount of nutrients it contains [2]. In Ecuador, there are geographical areas suitable for the production of bovine milk, and the sierra region constitutes the main producing region; which is distributed nationwide [3]. The province of Cañar, located in the south central zone, also contributes with important quantities in the production of national bovine milk [4]. Within the province, in the town of Suscal, numerous families are linked to this activity, where villagers from rural areas market the product in their own sector or it is sold to the processing plants, through which they obtain their main economic benefits [5]. The production, transport and marketing of milk in the country is supervised by Agrocalidad and ARCSA (National Agency for Regulation, Control and Sanitary Vigilance). The price of milk in the market of the Suscal town is around 0.25 to 0.30 cents (USD), depending on the supply by the intermediaries, however, there are dairies that pay for milk according its quality; based on the percentages of fat and protein [6]. On the other hand, the quality also implies the presence of pathogenic microorganisms, which, the milk, besides being a healthy and beneficial product, also constitutes as a culture medium for the microorganisms, in this way, constituting itself as a way of transmission of diseases [7]. However, several producers in the town of Suscal don't know about the quality of bovine milk, due to its high cost for the laboratory analysis as well as not knowing if the milk is suitable for consumption. Therefore, through the present study, it was proposed to determine the quality

\section{Journal of}

\section{Veterinary Science} \& Medicine

\author{
Heredia Peralta $\mathrm{DT}^{1,3}$, Simbaina Solano $\mathrm{JC}^{2 *}$ \\ 'Dairy Technician "Ambrosio Andrade Palacios". Cañar, Ecuador \\ ${ }^{2}$ Assitant researcher "University of Azuay". Cuenca, Ecuador. \\ ${ }^{3}$ Laboratory of Bromatology and Microbiology "NUTRI Leche" of \\ Dairy "San Antonio" \\ *Address for correspondence: \\ Simbaina Solano JC, Assistant researcher "University of Azuay" \\ Cuenca, Ecuador. Lanimetry Laboratory, Faculty of Veterinary and \\ Animal Sciences, University of Chile, Santa Rosa 11735, Santiago, \\ Chile. E-mail: austrogenetica@gmail.com \\ Submission: 25-November-2019 \\ Accepted: 28-December-2019 \\ Published: 30-December-2019 \\ Copyright: @ 2019 Heredia Peralta DT, et al. This is an open access \\ article distributed under the Creative Commons Attribution License, \\ which permits unrestricted use, distribution, and reproduction in any \\ medium, provided the original work is properly cited.
}

of bovine milk in the premises of the town of Suscal, establishing 3 sample collection areas: area 1 (Kolla Uko); area 2 (Ambrosio Andrade Palacios); area 3 (Gun Chico). For which, the following specific objectives were established: to carry out the physicochemical and microbiological analysis and organoleptic tests of bovine milk.

\section{Materials and Methods}

The present research work was carried out in different livestock herds of the Suscal farms. This town is located on the Durán-Tambo section of the Pan-American Highway in the province of Cañar, at an altitude of 2720 meters above sea level [8]. The research is descriptive and the experimental units are the cattle herds, where the physical, chemical, microbiological and organoleptic variables of the bovine milk were evaluated. The study areas were: Kulla Uko (KU), Ambrosio Andrade Palacios (AAP) and Gun Chico (GC), where milk samples were collected approximately $500 \mathrm{ml}$ per livestock farm, and with twenty repetitions per area.

\section{Laboratory analysis}

The $\mathrm{pH}$ of the milk was measured with the $\mathrm{pH}$ meter. Cow's milk has a weakly acid reaction, with a $\mathrm{pH}$ between 6.6 and 6.8 ; as a result of casein and phosphoric and citric anions $[9,10]$. Additionally, the acidity was determined using phenolphthalein and sodium hydroxide, where a $10 \mathrm{ml}$ milk sample was taken in a beaker, then 3 drops of the phenolphthalein indicator was added to $1 \%$, then sodium hydroxide was added on the dissolution until its turn [11]. According to the NTE INEN 9-13 test of normal raw milk, the acidity must be between minimum $0.13 \%$ or $13^{\circ} \mathrm{D}$ and maximum $0.17 \%$ or $17^{\circ} \mathrm{D}$. The degree of acidity demonstrates the level of microbial contamination that milk has [12]. On the other hand, the density, total solids, protein and fat were determined using the Ekomilk equipment [11], where 100 $\mathrm{ml}$ of milk was placed, and subsequently, its corresponding reading. According to the NTE INEN 9-11 standard raw milk test, the relative density must be between minimum $1.028 \mathrm{~g} / \mathrm{ml}$ to $1.029 \mathrm{~g} / \mathrm{ml}$ at 15 and $20^{\circ} \mathrm{C}$ respectively, and between maximum $1.032 \mathrm{~g} / \mathrm{ml}$ to $1.033 \mathrm{~g} /$ $\mathrm{ml}$ at 15 and $20{ }^{\circ} \mathrm{C}$ respectively. Additionally, according to the NTE INEN 9-14 standard raw milk test, total solids must be minimum 11.2 


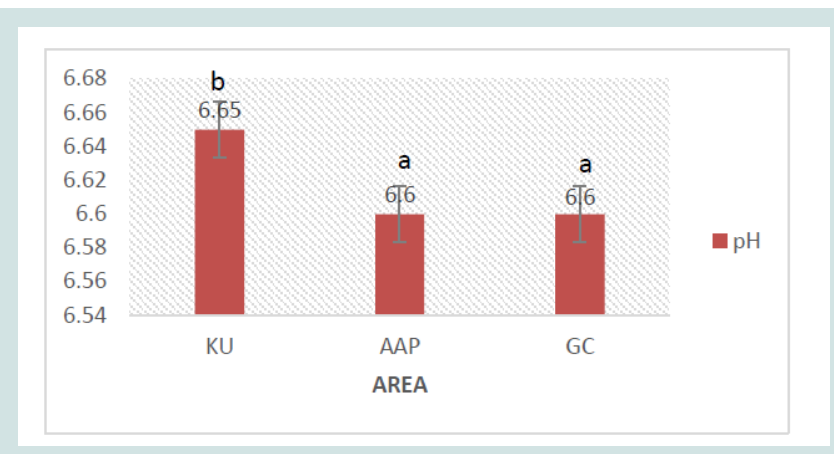

Figure 1: $\mathrm{pH}$ of milk per area

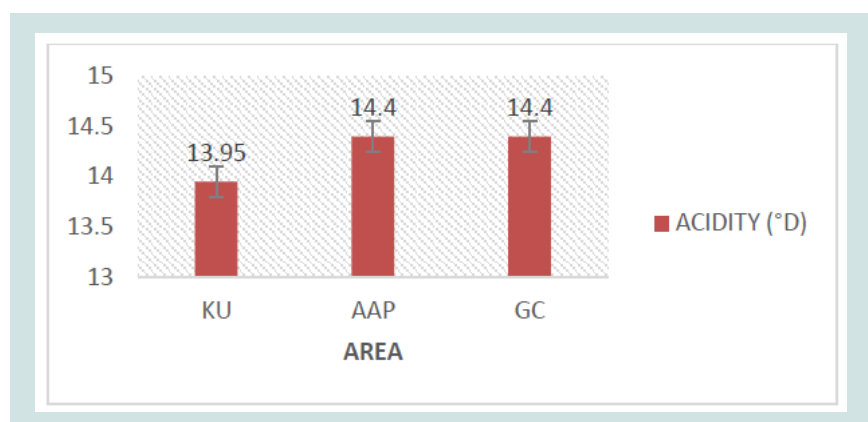

Figure 2: Milk acidity per area.

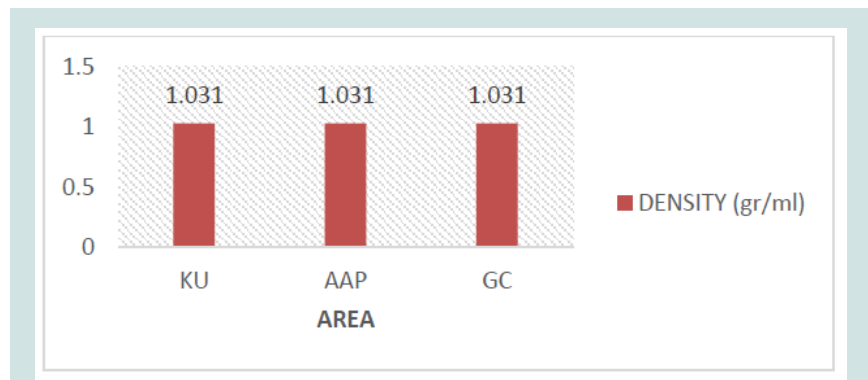

Figure 3: Milk acidity per area.

$\%$. Also, according to the NTE INEN 9-16 assay of normal raw milk, the protein must be minimum $2.9 \%$. Finally, according to the NTE INEN-ISO 2406 test of normal raw milk, the fat must be minimum $3.0 \%[12]$.

In the cultivation of mesophilic aerobes [13], $1 \mathrm{ml}$ of the milk sample was taken in a test tube and $0.1 \%$ peptone water was added, then it was homogenized, and subsequently, solutions D-4 and D-5 were made. Finally, $1 \mathrm{ml}$ of each solution was placed in the aerobic profiles for their respective culture at 24 and 48 hours in the stove at 31 ${ }^{\circ} \mathrm{C}$. The observation of the pink colonies in the profiles is an indicator of the presence of mesophilic aerobes, and the report is through the counting of the colonies in $1 \mathrm{~cm}^{2}$ [14]. According to the NTE INEN 1529-5 standard milk test, the aerobic colony count must be maximum $2 \times 10^{4}$ to $5 \times 10^{4} \mathrm{CFU}$ [12]. The Colony Forming Unit (CFU) in raw milk represents each growing colony of bacterial and fungal cells (fungi). Each colony represents a dozen million descendant cells [15]. Bacteria grow in pairs (diplococci), chain (streptococci) or clusters (staphylococci) [16]. Among the main bacteria that develop in fresh milk are E. coli and Listeria monocytogenes [13]. On the other hand, the EKOMILK somatic cells analyzer team [14] was used to determine the number of somatic cells, where $10 \mathrm{ml}$ of milk was placed with $5 \mathrm{ml}$ of the EKOPRIM reagent, and subsequently its respective reading. According to ISO 13366-1 standard milk test, the somatic cell count must be less than $5 \times 10^{5} \mathrm{u} / \mathrm{ml}[12,17]$. The number of somatic cells in raw milk is an indicator of leukocytes present in the mammary gland, which represents the health status of the udder $[14,18]$.

Finally, the organoleptic characteristics of bovine milk, was determined following the INEN 9: 2015 standards, where, the said norm establishes the ideal characteristics of a normal milk (color, smell and texture). For the evaluation of the evaluated variables, a scale of 1 to 5 was used, where 1 indicates a lower valuation (not ideal milk) and 5 the highest valuation (ideal milk). According to the norm NTE INEN 9: 2015 of the normal raw milk, the color must be opalescent white and slightly yellowish; the smell must be soft, characteristic milk and free of strange odors; and the texture must be homogeneous and free of foreign matters.

\section{Statistical analysis}

The data obtained were subjected to a multifactorial ANOVA using SAS software (Statistic Analysis Software) [19], where the factors of study were the different livestock farms areas and the evaluation variables were physicochemical, microbiological and organoleptic properties of bovine milk. For the separation of means, Tukey test was used at the level of significance $(\mathrm{P}<0.05)$. Additionally, Pearson's correlation test was used among the variables evaluated.

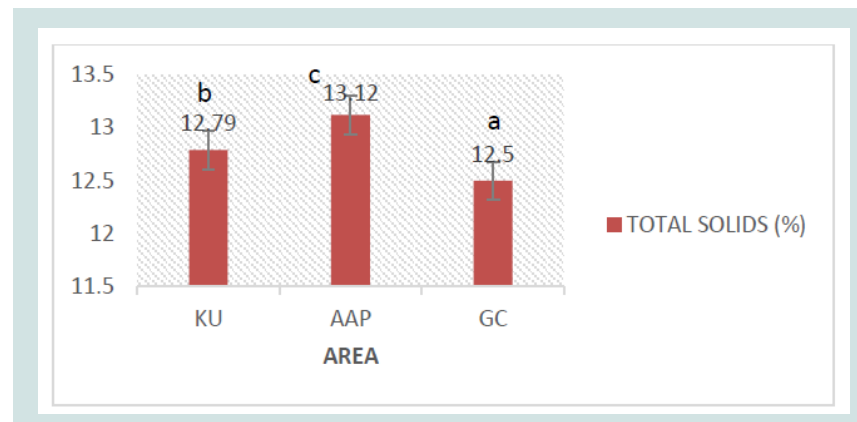

Figure 4: Total solids of milk per area.

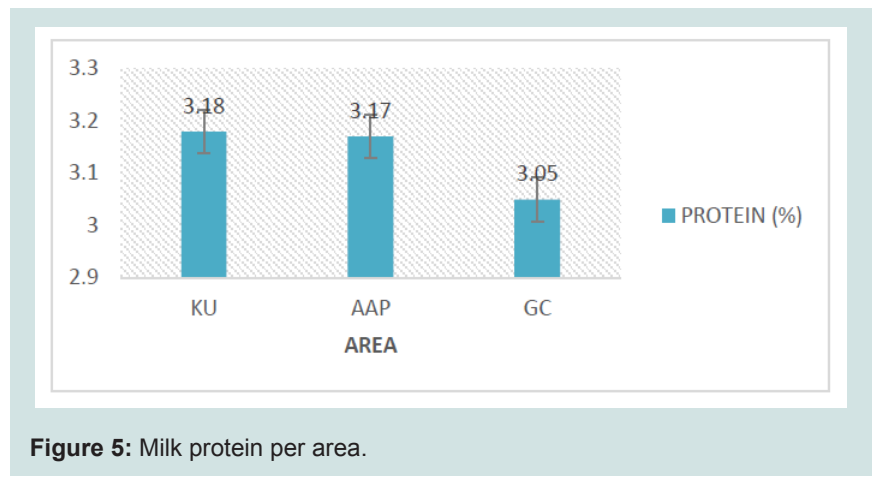


Citation: Heredia Peralta DT, Simbaina Solano JC. Evaluation of the Quality of Bovine Milk of the Livestock Farms of Suscal, Cañar, Ecuador. J Veter Sci Med. 2019;7(2): 5.

ISSN: $2325-4645$

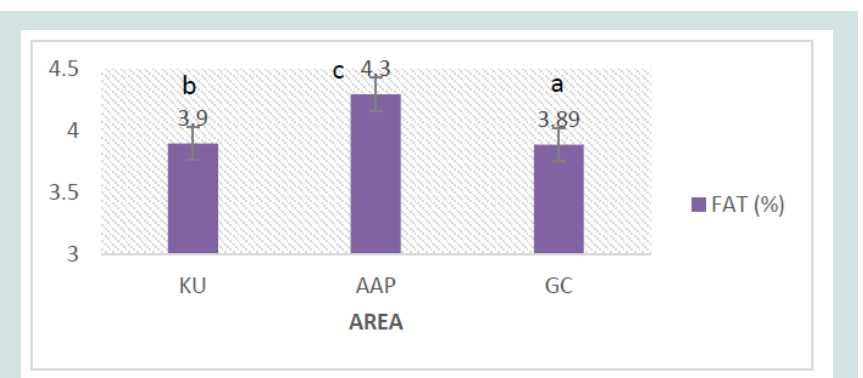

Figure 6: Milk fat per area.

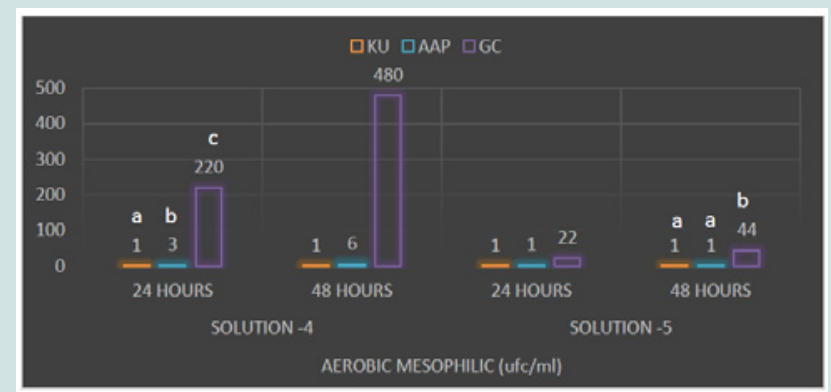

Figure 7: Aerobic mesophylls of milk per area.

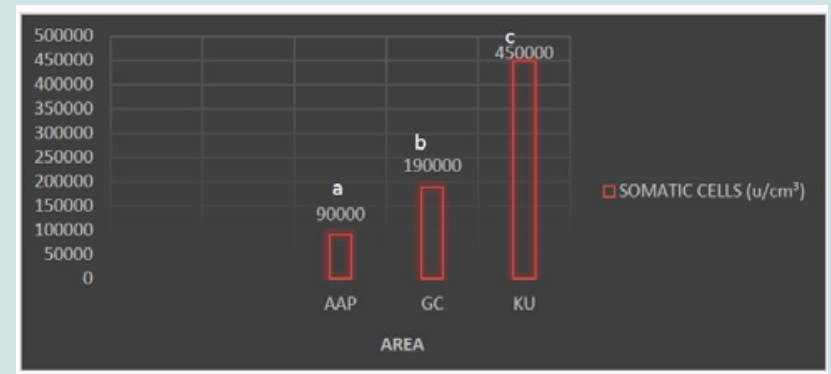

Figure 8: Somatic cells of raw milk per area.

\section{Results}

The general averages of physicochemical properties, microbiological analysis and organoleptic tests in Suscal livestock farms were detailed below (table 1).

\section{Physicochemical analysis per area}

The $\mathrm{pH}$ of the milk was of 6.65 in Kulla Uko area (KU); of 6.6 in Ambrosio Andrade Palacios area (AAP); and of 6.6 in Gun Chico area (GC), with significant differences $(\mathrm{P}<0.05)$, (Figure 1$)$.

The acidity of the milk was $13.95^{\circ} \mathrm{D}$ in $\mathrm{KU}$; of $14.4^{\circ} \mathrm{D}$ in AAP; and $14.4^{\circ} \mathrm{D}$ in GC, without statistical differences (Figure 2).

The density of the milk in the areas KU, AAP and GC was 1.031 $\mathrm{gr} / \mathrm{ml}$, without significant differences (Figure 3 ).

The total solids of the milk were of $12.79 \%$ in KU; of $13.12 \%$ in AAP; and of $12.5 \%$ in GC, with significant differences $(\mathrm{P}<0.05)$, (Figure 4).
The milk protein was $3.18 \%$ in $\mathrm{KU}$; of $3.17 \%$ in AAP; and $3.05 \%$ in GC, without statistical differences (Figure 5).

The milk fat was of $3.9 \%$ in KU; $4.3 \%$ in AAP; and of $3.89 \%$ in $\mathrm{GC}$, with significant differences $(\mathrm{P}<0.05)$, (Figure 6).

\section{Microbiological analysis per area}

The count of the colonies for mesophilic aerobes with solution -4 at 24 hours were $1 ; 3$ and 220 colonies in KU, AAP and GC respectively, with significant differences $(\mathrm{P}<0.05)$. Meanwhile, with the same solution -4 at 48 hours were $1 ; 6$ and 480 colonies in $\mathrm{KU}$, AAP and GC respectively, without significant differences. On the other hand, the count of colonies for mesophilic aerobes with the -5 solution at 24 hours were $1 ; 1$ and 22 colonies in KU, AAP and GC respectively, without significant differences. Meanwhile, with the same solution -5 at 48 hours were $1 ; 1$ and 44 colonies in KU, AAP and GC respectively, with significant differences $(\mathrm{P}<0.05)$ (Figure 7).

The count of the somatic cells in the raw milk were $<90 \mathrm{e} 3,190 \mathrm{e} 3$ and $450 \mathrm{e} 3 \mathrm{u} / \mathrm{cm}^{3}$ in the areas AAP, GC and $\mathrm{KU}$ respectively, with significant differences $(\mathrm{P}<0.05)$ (Figure 8$)$.

\section{Organoleptic test per area}

The color of the raw milk had a value of 4.25 points in AAP; 4.1 points in KU; and 4.2 points in GC, without significant differences. The odor of raw milk had a value of 4.75 points in AAP; 4.25 points in KU; and 4.45 points in GC, without significant differences. The texture or appearance of the raw milk had a value of 4.95 points in AAP; 4.8 points in $\mathrm{KU}$; and 4.95 points in GC, without significant differences (Figure 9).

\section{Correlation between the variables}

Total solids are highly correlated with the protein at $0.81(\mathrm{P}<0.01)$ and with fat at $0.89(\mathrm{P}<0.01)$, and they are positive. On the other hand, protein and fat are fairly correlated at $0.46(\mathrm{P}<0.01)$, and it's positive (Table 2).

\section{Discussion}

The physical and chemical characteristics of bovine milk, the $\mathrm{pH}$ of raw milk must be between 6.6 and 6.8 [9]. Arteaga (2016) reports the $\mathrm{pH}$ after making an improvement plan with the San Antonio dairy suppliers, with values of 6.69. In our results, 6.62 were reported.

On the other hand, according to the NTE INEN 9-13 test of

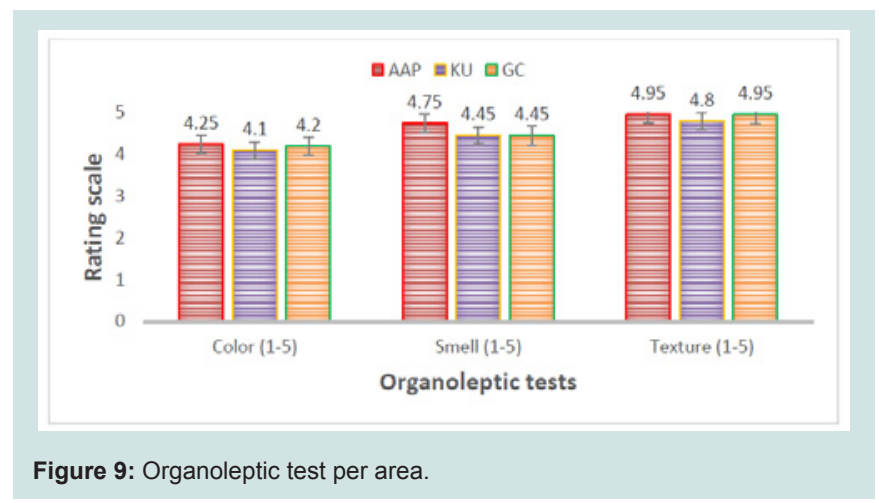


Citation: Heredia Peralta DT, Simbaina Solano JC. Evaluation of the Quality of Bovine Milk of the Livestock Farms of Suscal, Cañar, Ecuador. J Veter Sci Med. 2019;7(2): 5.

ISSN: $2325-4645$

Table 1: General averages of physicochemical properties, microbiological analysis and organoleptic tests in Suscal livestock farms.

\begin{tabular}{|c|c|c|c|c|c|c|c|}
\hline Physical-chemical properties & $\mathrm{n}$ & Mean & SD & SE & CV & Minimum & Maximum \\
\hline $\mathrm{pH}$ & 60 & 6,62 & 0,02 & 0,003 & 0,36 & 6,60 & 6,65 \\
\hline Acidity $\left({ }^{\circ} \mathrm{D}\right)$ & 60 & 14,25 & 0,21 & 0,03 & 1,50 & 13,95 & 14,40 \\
\hline Density (gr/ml) & 60 & 1,031 & 0,00 & 0,00 & 0,00 & 1,031 & 1,031 \\
\hline Total solids (\%) & 60 & 12,80 & 0,26 & 0,03 & 2,00 & 12,50 & 13,12 \\
\hline Protein (\%) & 60 & 3,13 & 0,06 & 0,01 & 1,90 & 3,05 & 3,18 \\
\hline Fat $(\%)$ & 60 & 4,03 & 0,19 & 0,02 & 4,78 & 3,89 & 4,30 \\
\hline Microbiological analysis & $\mathrm{n}$ & Mean & S.D. & S.E. & CV & Minimum & Maximum \\
\hline MAS-4.24h (cfu/ml) & 60 & 74,37 & 103,85 & 13,41 & 139,65 & 0,10 & 220,00 \\
\hline MAS-4.48h (cfu/ml) & 60 & 162,03 & 226,75 & 29,27 & 139,94 & 0,10 & 480,00 \\
\hline MAS-5.24h (cfu/ml) & 60 & 7,70 & 10,20 & 1,32 & 132,52 & 0,10 & 22,00 \\
\hline MAS-5.48h (cfu/ml) & 60 & 14,73 & 20,87 & 2,69 & 141,65 & 0,10 & 44,00 \\
\hline Somatic cells $\left(\mu / \mathrm{cm}^{3}\right)$ & 60 & 24333,33 & 15301,12 & 1935,77 & 62,88 & 9000 & 45000 \\
\hline Organoleptic tests & $\mathrm{n}$ & Mean & S.D. & S.E. & CV & Minimum & Maximum \\
\hline Color (Scale 1-5) & 60 & 4,18 & 0,81 & 0,10 & 19,43 & 3,00 & 5,00 \\
\hline Smell (Scale 1-5) & 60 & 4,55 & 0,70 & 0,09 & 15,37 & 3,00 & 5,00 \\
\hline Texture (Scale 1-5) & 60 & 4,90 & 0,35 & 0,05 & 7,23 & 3,00 & 5,00 \\
\hline
\end{tabular}

$\mathrm{pH}$ : potential of Hydrogen.

SD: Standard Deviation.

SE: Standard Error.

CV: Coefficient of Variation.

MAS-4.24h: Microbiological Analysis with Solution -4 at 24 hours.

normal raw milk, the acidity must be between minimum $0.13 \%$ (13 $\left.{ }^{\circ} \mathrm{D}\right)$ to $0.17 \%\left(17^{\circ} \mathrm{D}\right)$ [12]. Arteaga (2016) reports the acidity of 14.41 ${ }^{\circ} \mathrm{D}$ in San Antonio dairy products, and Quevedo (2019) of $0,15^{\circ} \mathrm{D}$. In our results, $14.25^{\circ} \mathrm{D}$ was reported. Therefore, our results are similar to the reports of Arteaga (2016) and Quevedo (2019), and are within the ranges established by the INEN 9: 2015 standard.

Additionally, according to the NTE INEN 9-11 standard raw milk test, the relative density must be at a minimum of $1.029 \mathrm{~g} / \mathrm{ml}$ to 1.028 $\mathrm{g} / \mathrm{ml}$ at 15 and $20^{\circ} \mathrm{C}$ respectively, and must be at a maximum of 1.032 $\mathrm{g} / \mathrm{ml}$ to $1,033 \mathrm{~g} / \mathrm{ml}$ at 15 and $20^{\circ} \mathrm{C}$ respectively [12]. Arteaga (2016), reports the density $1.030 \mathrm{~g} / \mathrm{ml}$, and Quevedo (2019) of 1,029 g/ml. In our results, $1.031 \mathrm{~g} / \mathrm{ml}$ was reported. Therefore, our results are similar to the reports of Arteaga (2016) and Quevedo (2019), and are within the range established by the INEN 9: 2015 standard.

In addition, according to the NTE INEN 9-14 trials; NTE INEN 9-16; and INEN-ISO 2406 of normal raw milk for total solids; protein; and fat, must be at least $11.2 \% ; 2.9 \% ; 3.0 \%$ respectively [12]. Arteaga (2016) and Quevedo (2019) report similar data. In our results we obtained percentages higher than these ranges, which indicates that they comply with the INEN 9: 2015 norm.

Regarding the microbiological analysis of bovine milk, according to the NTE INEN 1529-5 test of normal raw milk, the aerobic colony count must be maximum of $2 \times 10^{4}$ to $5 \times 10^{4} \mathrm{CFU}$ [12]. Our results report lower data with respect to the norm INEN 9: 2015, which indicates, a milk without major contamination. On the other hand, according to the ISO 13366-1 test of normal raw milk, the somatic cell count must be less than $5 \times 10^{5} \mathrm{u} / \mathrm{ml}$ [12]. Our results report below of INEN 9: 2015 and Quevedo (2019), which indicates that the health status of the udders was not very infected by pathogens which ensures a quality milk that can be consumed by the population.

As regards the organoleptic characteristics of bovine milk, according to the NTE INEN 9: 2015 norm of normal raw milk, the color must be opalescent white and slightly yellowish; the smell must be soft dairy characteristic and free of strange smells; and the texture must be homogeneous and free of foreign matters [20, 21]. Our results report scores of 4.18; 4.55; and 4.90 in color, smell, and texture respectively. Therefore, the organoleptic characteristics of the analyzed milk had values about 5 , that is, values that indicate an ideal milk, with qualities of texture, color and smell of a normal milk, fresh and suitable for consumption.

\section{Conclusion}

The microbiological analysis of bovine milk, by counting the Colony Forming Units (CFU) to determine mesophilic aerobes, our results do not ensure that the product is free of pathogens. Therefore, a specific analysis for each pathogen is recommended for future studies. However, by counting microorganism-forming colonies, we can verify a priori the degree of microbial contamination, and

Table 2: Pearson correlation between the variables.

\begin{tabular}{|c|c|c|c|c|}
\hline Variable(1) & Variable(2) & $\mathrm{n}$ & Pearson & $\mathrm{p}$-value \\
\hline Total solids \% & Protein \% & 60 & 0,81 & $<0,0001$ \\
\hline Total solids \% & Fat \% & 60 & 0,89 & $<0,0001$ \\
\hline Protein \% & Fat \% & 60 & 0,46 & 0,0002 \\
\hline
\end{tabular}

$\mathrm{n}$ : number of samples. 
Citation: Heredia Peralta DT, Simbaina Solano JC. Evaluation of the Quality of Bovine Milk of the Livestock Farms of Suscal, Cañar, Ecuador. J Veter Sci Med. 2019;7(2): 5.

thus, diagnose the quality of the product. Additionally, through the analysis of somatic cells, our result doesn't specify the pathogen contaminating the udders. In addition, the Kulla Uko (KU) area reports high amounts of somatic cells, about to the maximum limit recommended by the INEN 9: 2015 norm, although it doesn't differ statistically, consequently, it presents risks and dangers of propagation of these pathogens.

The organoleptic characteristics of the milk are fundamental to determine the quality of the product, since the product is highly perishable and captures strong and strange smells from the environment. Therefore, the analysis of the organoleptic tests is fundamental to determine the quality of the product. Additionally, it is recommended to consume the milk duly treated under pasteurization and sterilization techniques, since the fresh and raw product presents risks of contamination and transmission of diseases. Finally, the cost of analysis in the laboratory was $\$ 50.00$ (USD) per sample.

\section{References}

1. Navarro A (2017) Influencia de los factores dietéticos maternos durante la gestación en la calidad de la leche y su repercusión en el recién nacido. pp: 1-188.

2. Agudelo D, Bedoya O (2005) Composición nutricional de la leche de ganado vacuno. Rev Lasallista Investig. pp: 1-6.

3. Requelme N, Bonifaz N (2012) Caracterización de sistemas de producción lechera de Ecuador. La Granja. Pp: 1-14.

4. Pilco L (2002) Caracterización de los sistemas de producción mixtos: cultivos-ganadería de las comunidades campesinas de las provincias de Cañar y Chimborazo.

5. Ibáñez A (2015) Evaluación del tiempo de cuajado en las características organolépticas del queso fresco. pp:1-98.

6. Arteaga $L$ (2016) Implementación de un plan de mejoramiento de la calidad de la leche, de proveedores de lácteos San Antonio Cañar. pp: 1-110.

7. Rojas-Ronquillo M, Cruz-Bautista E, Daniel-Rentería I, LammogliaVillagómez M (2014) Determinación de la calidad microbiológica de la leche cruda de vaca durante la temporada invernal en Tuxpan, Veracruz.
1-6.

8. GeoDatos (2019) Coordenadas geográficas de Ecuador. Latitud y longitude.

9. Guevara-Freire D, Montero-Recalde M, Rodríguez A, Valle L, Avilés-Esquivel D (2019) Revista de Investigaciones Veterinarias del Perú. Calidad Quality of milk collected in small farms of Cotopaxi, Ecuador. Rev Investing Vet. pp: 247-255.

10. Jacho G, Pulamarin E (2015) Elaboración de un manual técnico de procesamiento de lácteos. Cayambe, Pichincha. pp: 1-358.

11. Guerrero J, Rodríguez P (2009) Características físico-química de la leche y su variación. Estudio de caso, Empresa de lácteos El colonial, León, Nicaragua., Universidad Nacional Agraria. pp: 1-72.

12. NTE INEN 9 (2012) Instituto Ecuatoriano De Normalización. Leche cruda Requisitos. Norma Técnica Ecuatoriana. pp: 1-7.

13. Álvarez-Fuentes G, Herrera-Haro JG, Alonso-Bastida G, Barreras-Serrano A (2012) Calidad de la leche cruda en unidades de producción familiar del sur de Ciudad de México. Arch Med Vet. pp: 237-242.

14. Bradley A, Green M (2005) Use and interpretation of somatic cell count data in dairy cows. In Pract. pp: 310-315.

15. Calderon A, Rodríguez V, Arrieta G, Martinez N, Vergara O (2012) Calidad fisicoquímica y microbiológica de leches crudas en empresas ganaderas del sistema doble propósito en montería (córdoba). pp: 1-9.

16. Motta L, Alexander B, Brenda M et al (2018) Análisis del recuento de la población bacteriana de muestras de leche no pasteurizada. Rev Sanid Mil. pp: 366-367.

17. Quevedo V (2019) Control de calidad de leche cruda en las provincias de Azuay y Cañar. Revista Ecuatoriana de Ciencia Anim. pp: 1-6.

18. Hernández R, Bedolla JM, Carlos JL (2008) Importancia del conteo de células somáticas en la calidad de la leche. REDVET.

19. Khattree R, Naik DN (2018) Applied Multivariate Statistics with SAS Software. $\left(2^{\text {nd }}\right.$ edn) Cary, NC, USA: SAS Institute Inc. pp: 1-363

20. Martínez Vasallo A, Villoch Cambas A, Ribot Enríquez A, Ponce Ceballo $P$ (2014) Diagnóstico de Buenas Prácticas Lecheras en una cooperativa de producción. Rev Salud Anim. pp: 14-18.

21. Barreto C, Norbey É (2006) Evolución de la calidad higiénica, composiciona y sanitaria de la leche cruda en Colombia conforme con el acuerdo de competitividad de la cadena lacteal. pp: 1-163. 